\title{
New firm's measures at the initial performance of Indian IPOs: A Binary Probit analysis
}

\author{
Rohit Bansal* and Ashu Khanna \\ Indian Institute of Technology, Roorkee, Uttrakhand, India - 247001.
}

Accepted 28 September, 2012

\begin{abstract}
This paper examines the impact on under pricing and firm market value arising from IPO firms implementing a range of Ex-ante uncertainty attributes such as the new firms, according to their incorporation of the year. Furthermore, we analyzed the several determinants of Ex-ante uncertainty such as subscription rate, issue size, market capitalization and ownership pattern and test the relationship between Ex-ante uncertainty and underpricing. We dealt with firms as new firms, which have been started their business since last one to five years. Using a comprehensive sample of 82 listed IPO firms from across India. We tested binary probit regression (Quadratic hill climbing) and QML (Huber/White) standard errors and covariance. Evidence was encountered a mixed impact from the New firm's on the Ex-ante uncertainty, that is subscription rate, issue size, market capitalization and non institutional non promoters have a significant association with a degree of underpricing of New firms. McFadden R-squared obtained $26.2 \%$ value.
\end{abstract}

Key words: IPO, underpricing, Probit analysis, BSE, Indian capital market, new firms measures, IPOs performance.

\section{INTRODUCTION}

In both the empirical and theoretic paradigms, one of the most examined phenomena in the finance literature is the pricing of Initial Public Offerings (IPOs). Arguably, the primary attraction of this subject to researchers is the empirically identified first trading day return (underpricing) which on average exceeds 18\% (Ibbotson and Ritter, 1995). Under the standard financial theory of efficient markets, such a predictable one-day return should not exist. Numerous theoretical models treat this observed initial return as an equilibrium return. For example, bookbuilding theories such as Benveniste and Spindt (1989), and Bansal and Khanna (2012) argue that issuer conditions its final offer price and share quantity on information acquired through its underwriter's bookbuilding effort, and that initial returns are compensations to informed investors for revealing their private information about the value of the IPO firm.
An alternative explanation is that some portion of the initial return reflects a supra-equilibrium return and that the efficient market hypothesis is violated. However, access to these undervalued securities is rationed. Some evidence documents that this market is inefficient is provided by Loughran and Ritter (1994), who demonstrate the initial returns are correlated with market returns before the offering, suggesting that public information is not fully incorporated into the offer price (Figures 1 and 2). New firm's age is a variable of Ex-ante uncertainty, while the calculated level of underpricing.

In this paper, we examine the association between firm firms with another Ex-ante uncertainty and to evaluate the probability however, older firms are less underpricing or less affected the degree of Ex-ante variables. We test binary Probit regression using new issuing IPO firm's (dummy variable) as 1 other 0 . In new issuing IPO firm's,

*Corresponding author. E-mail: rohitbansaliitr@gmail.com, rohitdpt@iitr.ernet.in. Tel: +919927285001.

JEL Classification: G12, G14, G32, G82. 
Initial Return

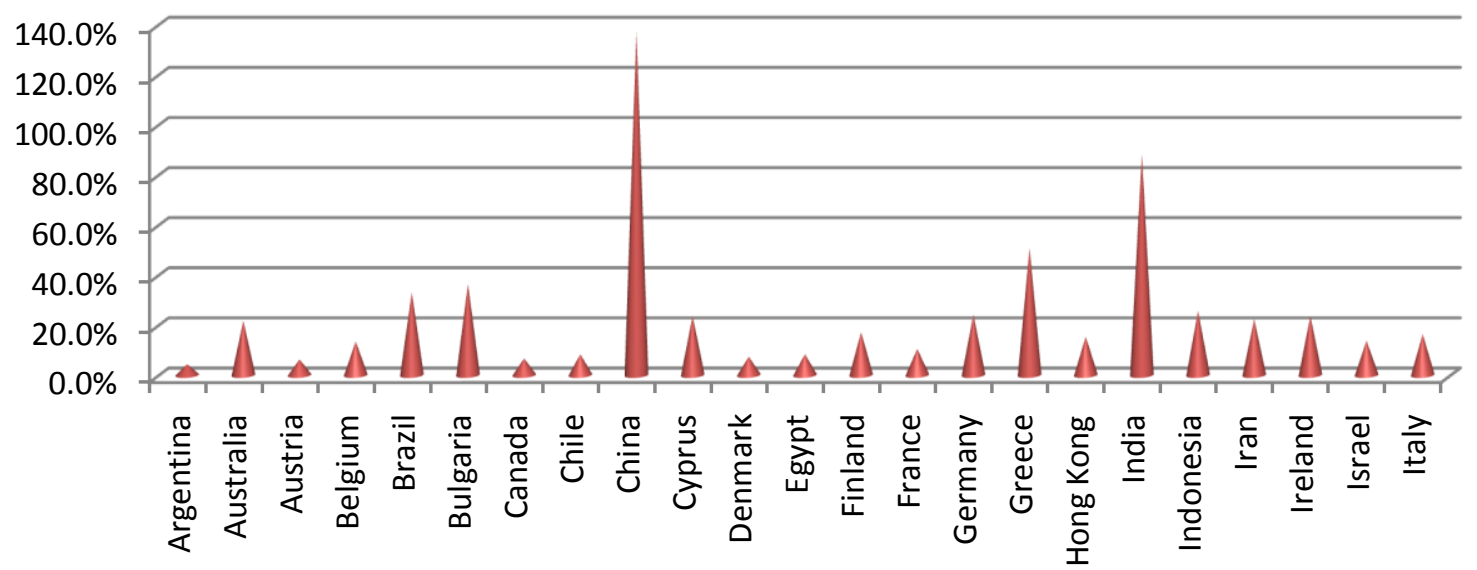

Figure 1. Initial return on IPO underpricing.

Source: (Loughran et al., 1994) 'Initial Public Offering: International Insights' (1994, updated 2012).

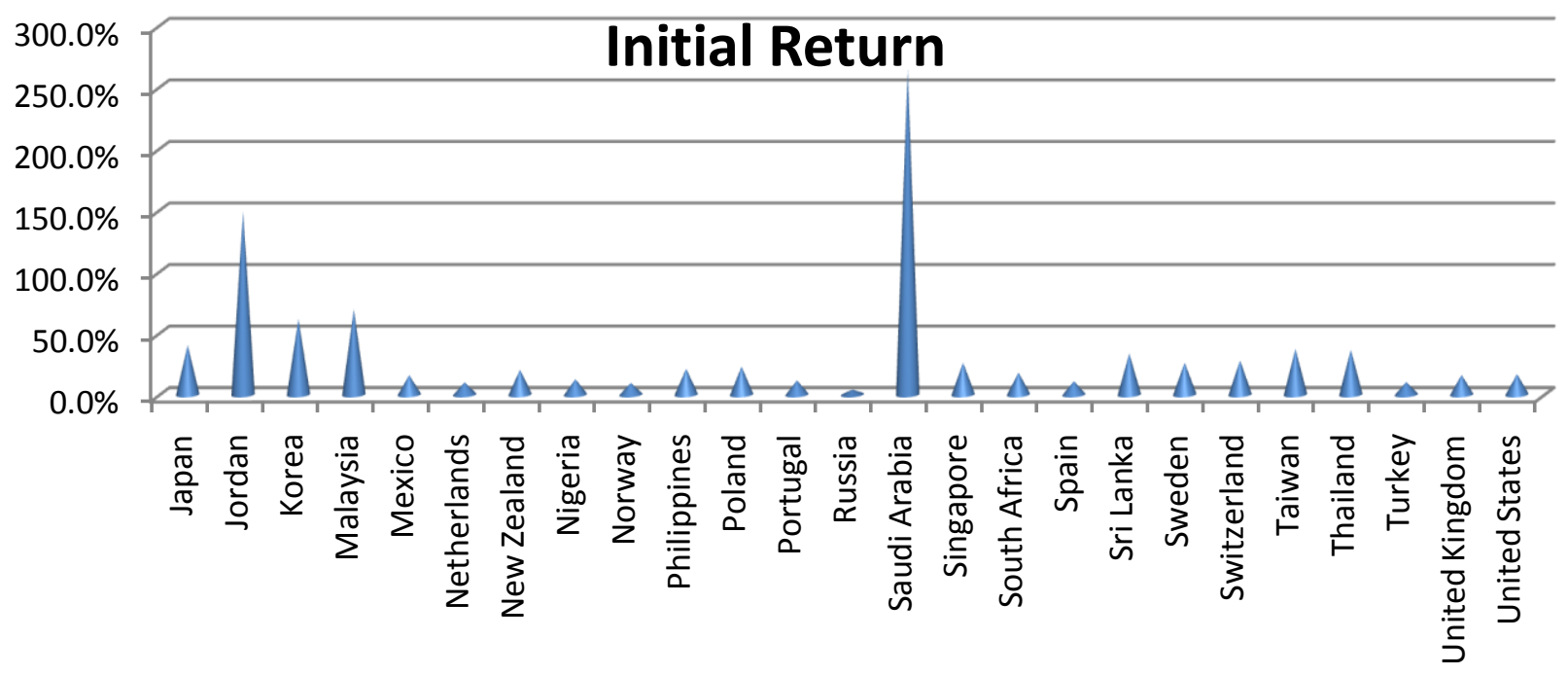

Figure 2. Initial return on IPO underpricing.

Source: (Loughran et al., 1994) 'Initial Public Offering: International Insights' (1994, updated 2012).

we embody those firms which are incorporated their business according to Indian company Act, 1956 and started their business since 1 to 5 years. We distribute 1 to those firms which is started their business since 1 to 5 years otherwise 0 . Probit regression discloses the relationship between new firms and other Ex-ante uncertainty variables. We tested QML (Huber/White) standard errors and covariance and Convergence achieved after 6 iterations and the Mc Fredmann R square.
The remainder of the paper is organized as follows. Surveys on the main reasons companies go public, and the ensuing preference for issuing firm's age is discussed. A sample of 82 Indian IPOs over the period (Oct 2008 to Dec- 2011) is described (Figure 3 and 4). The next section analyzes the determinants of the Ex-ante uncertainty and investigates the nature of trade-off between Firm's age and E-ante uncertainty. Also, methodology and Probit regression are discussed. Result and discussion are elaborated. Finally, concludes the paper. 


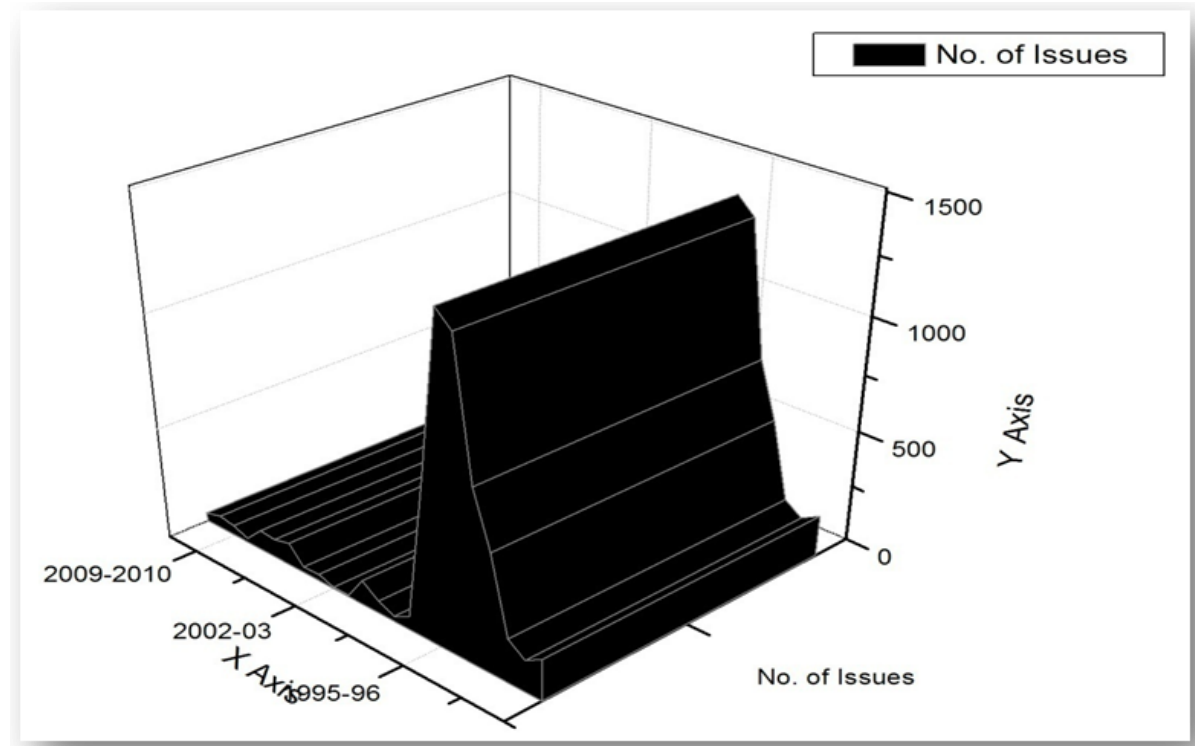

Figure 3. Number of IPOs issued at BSE from (1995-2011)

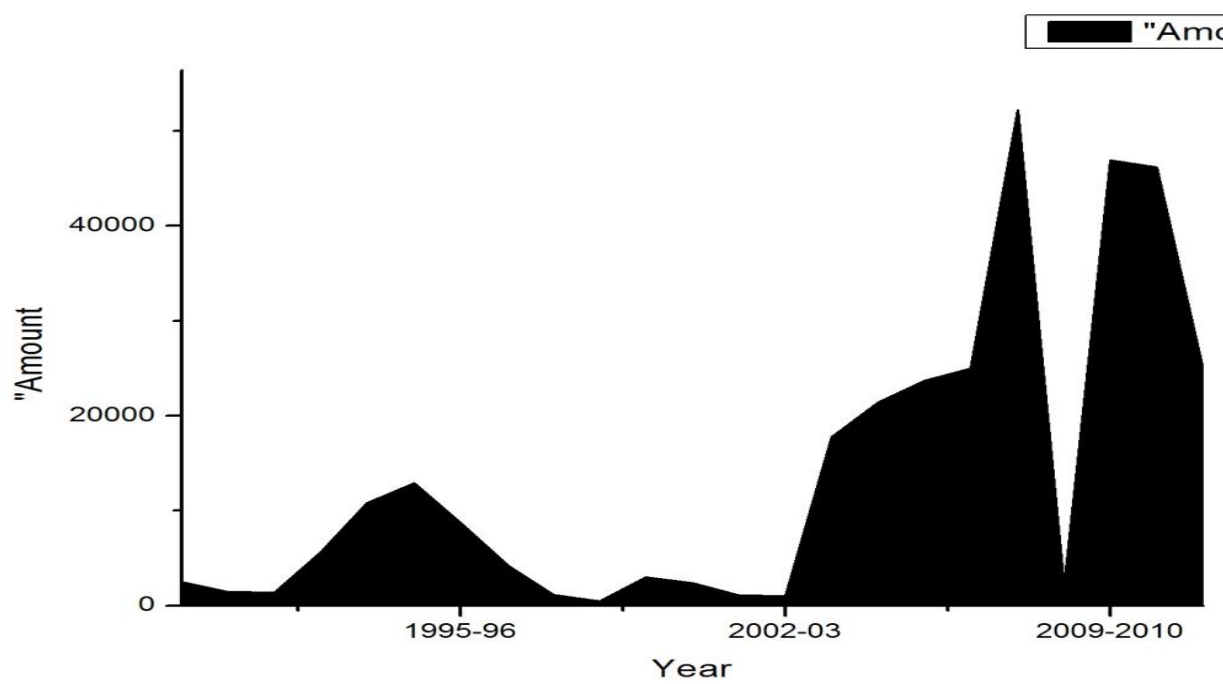

Figure 4. Total amount raised through IPOs from (1995-2011)

\section{Pricing mechanism}

In a fixed -price offering (Fixed), the offer price is published in the prospectus without information gathering from potential investors. An increase in asymmetric information would lead to a winner's curse phenomenon, decreasing the participation of uninformed investors (Rock, 1986). Firms would accordingly be forced to underpriced their shares in order to induce the first bids and create positive price cascades among investors (Welch, 1989). The need for a new procedure that reduces asymmetric information justifies the use of auction-like procedures (Figure 5 and 6).
Book-building efforts can either be aimed entirely at investors whose indications of interests are sought, or they can require some participation by retail investors, that is, hybrid offerings. In this framework, underwriters may propose a retail tranche with an offer price that is either fixed (a fixed-price offer), or non-fixed (an openprice offer). In a hybrid offering where a book-building mechanism is combined with a fixed-price offer issuers and underwriters the offer price at the end of the premarket period. Retail investors are less subject to the adverse selection problem observed in a pure fixed-price offer. Nevertheless, as retail investors can condition their demand based upon revealed interests in the book, 


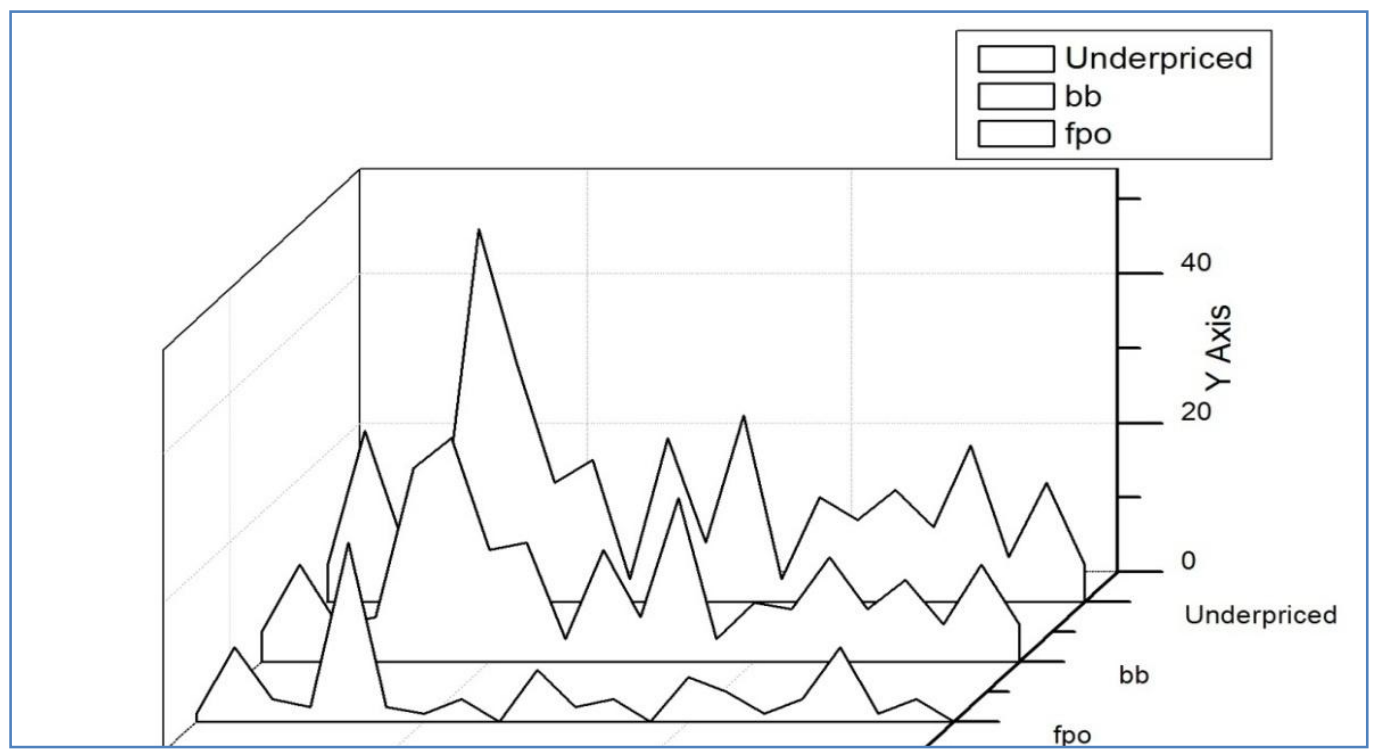

Figure 5. Details of IPO underpriced by different pricing mechanism

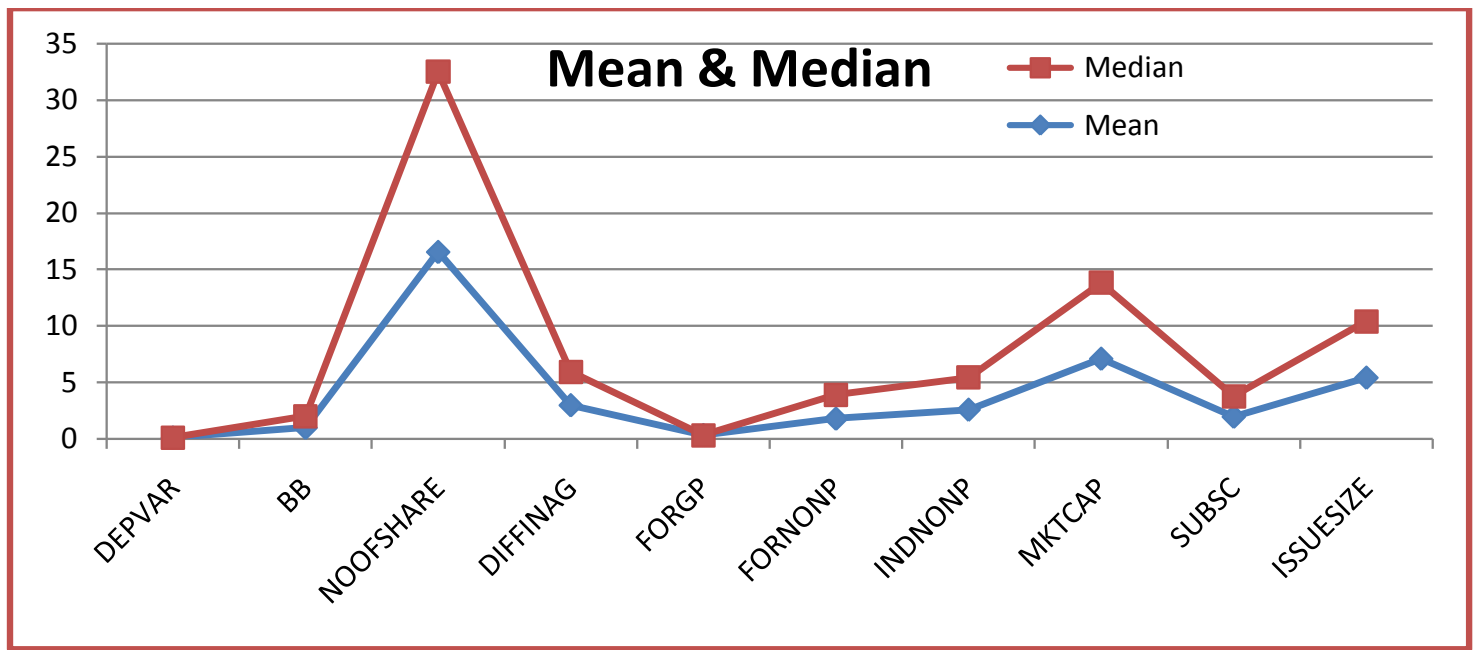

Figure 6. Mean and median value for Ex-ante uncertainty variables

hybrid mechanisms can cause cascades and thus higher underpricing. This explains the increased use of hybrid book-building procedures combined with an open-price offer. In this system, both open-price and book-build offerings are run simultaneously, and retail investors submit their orders in parallel to institutional investors.

\section{Theories and models of underpricing}

Therefore, a number of competing theoretical models have been developed to explain the initial underpricing of stocks. The main theories found in the IPO literature are the winner's curse hypothesis, book-build theories, and the principal-agent hypothesis, signaling theories, the law-suit avoidance hypothesis, the ownership and control hypothesis and the investor sentiment theory. One of the most important models of underpricing is the one developed by Rock (1986) based on the winner's curse hypothesis. Rock distinguishes between informed and uninformed investors. If the issues are underpriced, IPOs will be oversubscribed by informed investors, resulting in a limited number of shares being available to uninformed investors. If the issues are overpriced, IPOs will be sold exclusively to uninformed investors who will earn negative initial returns. Thus, uninformed investors will be 


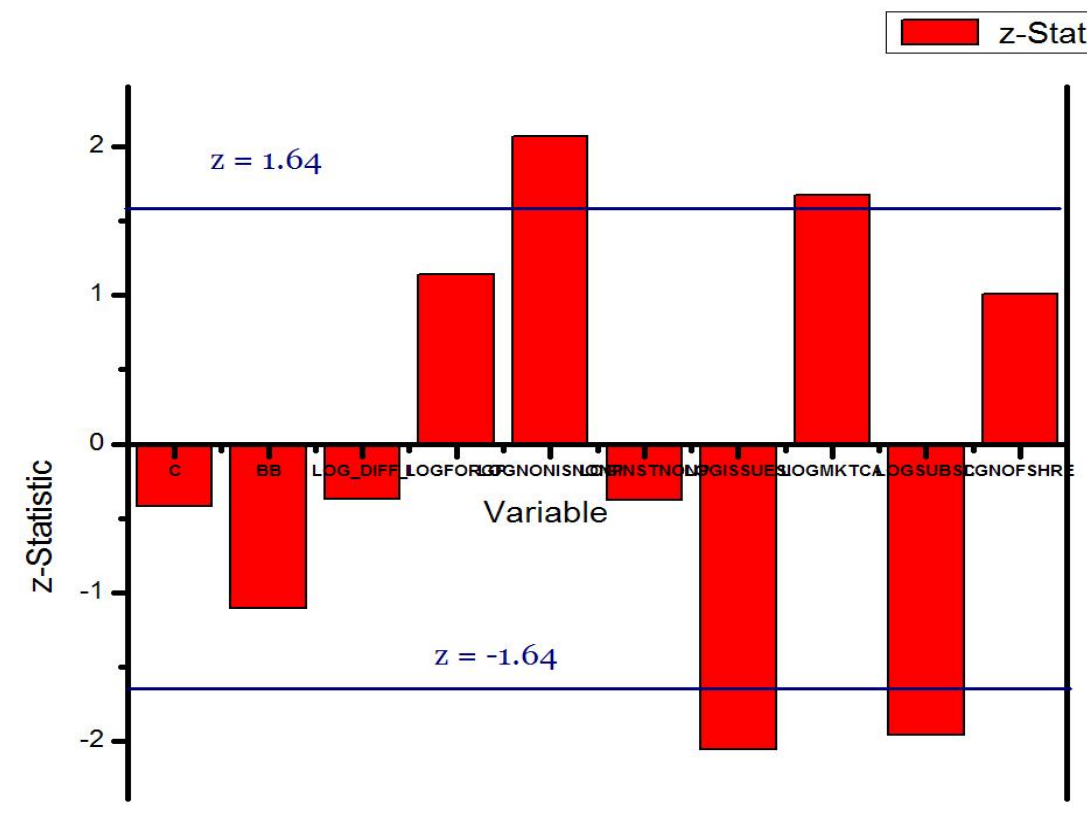

Figure 7. Results of $z$ statistics.

winning the entire issue but at an unfavorable price, creating a situation termed the winner's curse. In order to keep uninformed investors in the IPO market, securities are offered at a discount from their expected after market prices. Thus, according to the winner's curse theory, IPO underpricing should decrease if the information asymmetry between informed and uninformed investors is reduced.

Empirical studies have found evidence that the underpricing for IPOs of financial institutions is related to proxies for asymmetric information. Signaling (Allen and Faulhaber, 1989), asymmetric information (Ibbotson, 1975), offer size (Megginson and Weiss, 1991) age of the firm (Muscarella and Vetsuypens, 1989), market capitalization (McDonald and Fisher, 1972; Baker and Wurgler, 2007), pricing mechanism (Bansal and Khanna, 2012a), determinants of IPO underpricing at NSE (Kumar, 2010).

\section{Research objectives}

To measures, the IPOs initial performance on first trading day. The aim of our study is to determine and analysis the various Ex-ante uncertainty determinants that affect the level of underpricing. However, we also used Probit regression to find out the relationship between new firm's performances with several Ex-ante uncertainty variables that is issue size, number of shares offered, pricing mechanism, ownership structure, and market capitalization are used in the model.

\section{RESEARCH METHODOLOGY}

We allocation the level of underpricing of IPOs listed on the Bombay stock exchange from (October 2008 to December 2011), using the conventional method, where the raw initial return (RIR) on the first day of trading is calculated using Equation 3. However, we considered methodology for selection of several explanatory variables into our regression model. As the result of, one possible strategy may be obvious: include every potentially useful predictor and then delete those terms not making significant partial contributions at some reassigned level. Unfortunately, this usually is inadequate. Because of correlations among the explanatory variables, any one variable may have little unique predictive power, especially when the number of predictors is large. It is conceivable that few, if any, explanatory variables would make significant partial contributions, given that all of the other explanatory variables are in the model.

\section{Data description and sample selection}

Comprehensive lists of IPOs and listings were obtained direct from the Bombay stock exchange of India for the period (October 2008 to December 2011). These were cross checked with national stock exchange websites, and from similar lists obtained from major brokerage houses to ensure accuracy in the case of India. It resulted in a list of 100 listings having taken place across the region during the period (October 2008 to December 2011). We removed 18 IPO due to the unavailability of their firm-related data. Final sample size is 82 IPOs that were listed at Bombay stock exchange. The sample contains only common and ordinary stocks. Preference stock as well as transfer from Parallel to Main market is excluded. All data are mainly extracted from IPOs prospectuses, daily press, SEBI reports (History of BSE, Fact Books, Annual and Monthly Statistical Bulletins), Annual Reports of Reserve bank of India, $\mathrm{SEBI}$ and some special internet sites.

The prospectuses existed referenced from the library and 
website of BSE and SEBI resource centre. Data for each of the issues regarding the offer price, total gross proceeds, age of IPOs companies, the proportion of shares sold by owners, list of underwriters, earnings forecast, the closing date of the offer, are extracted from the prospectuses. Additional information on the companies was extracted from databases available at the public libraries of BSE and Capital Market, the library at the Reserve Bank of India, and the Prowess and Capitaline. In a few cases, we approached companies directly. The data was collected in two stages. First, we identified the IPOs and a number of offering characteristics. These were identified from annual issuing statistics provided in professional publications, financial press and when necessary, direct contact with the issuing company. Second, we obtained data from three sources, namely, website of SEBI (for prospectuses of IPOs), Stock exchange sites BSE (for public issue related data), and Prowess database of Centre for Monitoring Indian Economy or CMIE (for post-issue financial data).

\section{Measure of underpricing}

Firstly, we calculate the return on i security, where we used $\mathrm{Ri}=$ $(\mathrm{P} 1-\mathrm{P0}) / \mathrm{P0}$ in which, $\mathrm{Ri}=$ return on $\mathrm{i}$ security, $\mathrm{P} 1=$ Price of $\mathrm{i}$ security on first listing day, $\mathrm{P} 0=$ offer price of $\mathrm{i}$ security.

$R i=(P 1-P 0) / P 0$

Secondly, we calculate index return on corresponding days, where we used $\mathrm{Mi}=(\mathrm{li}-10) / 10$ in which, $\mathrm{Mi}=$ market return on ith day, $\mathrm{li}=$ closing index at listing day, $10=$ closing index at offer day.

$\mathrm{Mi}=(\mathrm{Ii}-10) / 10$

where $\mathrm{P} 1$ is the offer price of the firm $\mathrm{i}, \mathrm{P} 0$ is the first day closing prices of the shares in firm $\mathrm{i}$, and $\mathrm{Ri}$ is the total first day return on the stock. If markets are highly volatile such that there is a major change in the price of most stocks during the IPO period, then initial returns should be market adjusted. To compute the first day market adjusted return, the return of the market index is initially calculated as is the closing value of the market index on the issue date corresponding to the offering by firm $\mathrm{i}$ and $\mathrm{P} \mathrm{m} 0$ is the value of the market index corresponding to the offering price of the firm i. The market adjusted return abnormal return for each IPO on the first trading day is therefore computed as: MAARO

Finally, we calculate market adjusted return on security, where we taken Ri from Equation (1) and Mi from Equation (2).

Maaro $\left.=\left\{100^{*}[(1+\mathrm{Ri}) / 1+\mathrm{Mi})-1\right]\right\}$

\section{Hypothesis modeling}

On the based on our research problem, research objectives and empirical evidence about Ex-ante uncertainty and IPO underpricing, we formulated several hypotheses to check and test the validity and robustness of our results. We procure one-tailed t statistics and test it at $5 \%$ significance level.

Null Hypothesis, HO: There is no significant difference between several independent variables with the level of underpricing.

\section{Measure of pricing mechanism}

For the pricing mechanism again a dummy variable is used to indicate the presence of book build in IPO underpricing. The presence is shown with value equal to 1 and 0 otherwise.
H1: There is negative link between book build pricing mechanism and level of underpricing

\section{Offer timing (Difference between in days from offer date and listing date)}

Offer timing is a difference in days between the offer date and the first day listing date of IPOs. We transformed it into natural logarithm to make it as standard practice.

H2: There is positive association between book build pricing mechanism and level of underpricing

\section{Measures of ownership structure}

The ownership structure of a company comprises of a distribution of the size of investor shareholdings. Applying a single measure in the form of a proportion is to be sufficient to delineate distributions with varying shapes. Numbers of shares are holding by promoters and non promoters. We have also taken the total percentage of their shares holding in the ownership structure. Afterwards we have converted it into the natural logarithms to make standardized value and to remove the heteroscadisticity.

H3: There is positive significant relationship between Indian promoters and degree of underpricing.

H4: There is positive relationship between intuitional non promoters and level of underpricing.

H5: There is positive link between non intuitional non promoters and level of underpricing.

\section{Measure of issue size (total amount to be raised)}

The issue size is measured as the total number of shares offered multiplied by the offer price. Again, the natural logarithm of this value is used as a standard practice and to remove heteroscadisticity.

H6: There is negative significant connection between issue size and level of underpricing.

\section{Measure of market capitalization}

The market capitalization is measured as the total number of shares multiplied by the market price per share. Again, the natural logarithm of this value is used as a standard practice and to remove heteroscadisticity.

H7: There is optimistic significant relationship between market capitalizations and less underpricing.

\section{Measure of subscription}

The subscription is measured as the total number of shares acquired by several investors on the day of offering. Again, the natural logarithm of this value is used as a standard practice and to remove heteroscadisticity.

H8: There is negative relationship between subscription and level of underpricing.

\section{Measure of number of share offered}

Number of share offered is measured by the total quantity of shares 
Table 1. ANOVA and WELCH result

Test for equality of means between series

Sample: 182

Included observations: 82

\begin{tabular}{lccc}
\hline Method & df & Value & Probability \\
\hline ANOVA F-test & $(9,810)$ & 1335.188 & 0.0000 \\
Welch F-test $^{\star}$ & $(9,318.70)$ & 1729.189 & 0.0000
\end{tabular}

*Test allows for unequal cell variances

Analysis of variance

\begin{tabular}{lccc}
\hline Source of variation & df & Sum of Sq. & Mean Sq. \\
\hline Between & 9 & 17961.65 & 1995.739 \\
Within & 810 & 1210.728 & 1.494726 \\
Total & 819 & 19172.38 & 23.40950
\end{tabular}

Category statistics

\begin{tabular}{lcccc}
\hline Variable & Count & Mean & Std. Dev. & Std. err. of mean \\
\hline DEPVAR & 82 & 0.1097 & 0.31450 & 0.034732 \\
BB & 82 & 0.97561 & 0.15520 & 0.017140 \\
LOG_DIF_IN_A & 82 & 2.97007 & 0.21591 & 0.023844 \\
LGNOOFSHAR & 82 & 16.55044 & 1.507279 & 0.166451 \\
LOGMKTCAP & 82 & 7.095889 & 1.935683 & 0.213760 \\
LOGISSUESIZE & 82 & 5.416361 & 1.619507 & 0.178845 \\
LOGFORGP & 82 & 0.328417 & 1.033727 & 0.114156 \\
LOGFORNONP & 82 & 1.782401 & 1.284191 & 0.141815 \\
LOGINDNONP & 82 & 2.572124 & 1.334836 & 0.147408 \\
LOGSUBSC & 82 & 1.958564 & 1.279276 & 0.141272 \\
All & 820 & 3.975963 & 4.838336 & 0.168962 \\
\hline
\end{tabular}

that issuing firm has offered to their investors. Afterwards we have converted it into the natural logarithms to make standardized value and to remove the heteroscadisticity.

H9: There is positive relationship between number of share offered and degree of underpricing.

\section{RESULTS ANALYSIS}

\section{ANOVA and WELCH test result}

Based on Table 1, it display the ANOVA value as 1335.18 and the probability approx. $(0.00)$ at the degree of freedom 819 reveals the validity of ANOVA about the mean, variance between new firm' age and Ex-ante uncertainty variables. Nevertheless, Welch 'F' test discloses the value of 1729.18 with probability approx. $(0.00)$, verified the assumption of Welch's test about robustness of the model for firm's age and all Ex-ante uncertainty.

\section{Descriptive statistics}

Table 2 reveals that the mean value for all variables $(0$, $.10, .97,16.55,2.97, .32,1.78,2.57,7.09,1.95,5.41)$. It indicates the highest mean value is 7.09 for market capitalization and low is 0.10 for new firm's age. Accordingly, Standard deviation value is describes for the features for all Ex-ante variables.

Table 3 summary statistics of the variables used in this study are re-ported in Table 4. Average initial return for the entire sample is $34.9 \%$. McGuinness (1992) report underpricing of more than $100 \%$ during 1991 to 2006 . Therefore our result indicates that the IPO market in India has matured post year 2006. Table Reveals magnitudes of IPOs after the Indian stock market crisis since (October 2000 to Dec 2011). It is divided based on IPO that listed via book build and fixed price option. It is also disclose \% of underpricing and overpricing in different years. It differentiates issue that is priced through the 
Table 2. Description for Several variables used in regression model

\begin{tabular}{|c|c|c|c|c|}
\hline Variables & $\begin{array}{l}\text { Symbol used in } \\
\text { models }\end{array}$ & Description & $\begin{array}{l}\text { Variable/ } \\
\text { Dummy }\end{array}$ & $\begin{array}{l}\text { Expected } \\
\text { sign }\end{array}$ \\
\hline Maaro & Maaro & $\begin{array}{l}\text { Market adjusted abnormal return is calculated by difference between the offer price of share and first day market closing } \\
\text { price. }\end{array}$ & Dependent & - \\
\hline Pricing mechanism & IPO_TYPE & $\begin{array}{l}\text { Pricing mechanism is divided into two parts, Book build Pricing mechanism and Fixed option pricing mechanism. } \\
\text { However, we introduced pricing mechanism as a dummy variable into our models. As the result of, all those IPOs, issued } \\
\text { by book build marked as } 1 \text { otherwise } 0 \text {. }\end{array}$ & Dummy & Neg \\
\hline $\begin{array}{l}\text { Number of shares } \\
\text { issued to public }\end{array}$ & LGNOOFSHARE & $\begin{array}{l}\text { Company issued several numbers of shares to public, raised money via their subscription. However, we transformed it } \\
\text { into Natural logarithm and to find the impact of number of shares with the level of underpricing. }\end{array}$ & $\begin{array}{l}\text { Explanatory/ } \\
\text { Indp }\end{array}$ & Neg \\
\hline Difference in Days & LOGDIFF_IN_AG & Offer timing is measured by taken difference in days the between the offer date of the IPO and the listing date of an IPO. & $\begin{array}{l}\text { Explanatory/ } \\
\text { Indp }\end{array}$ & Pos \\
\hline $\begin{array}{l}\text { Total amount of Issue } \\
\text { size }\end{array}$ & LOGISSUESIZE & $\begin{array}{l}\text { Total amount is raised by company via IPOs issue of IPOs to public. However issue size is effect the percentage of } \\
\text { underpricing. }\end{array}$ & $\begin{array}{l}\text { Explanatory/ } \\
\text { Indp }\end{array}$ & Neg \\
\hline $\begin{array}{l}\text { Company's market } \\
\text { capitalization in listing } \\
\text { day }\end{array}$ & LOGMKTCAP & $\begin{array}{l}\text { The market capitalization is measured as the total number of shares multiplied by the market price per share. Another } \\
\text { time, the natural logarithm of this value is used as a standard practice and to remove heteroscadisticity. }\end{array}$ & $\begin{array}{l}\text { Explanatory/ } \\
\text { Indp }\end{array}$ & Neg \\
\hline Subscription rate & LOGSUBSC & $\begin{array}{l}\text { The subscription measured as the quantity of shares of the total times had investors subscribe after the issue. The } \\
\text { natural logarithm of this value is used as it is a standard practice and to remove heteroscadisticity. }\end{array}$ & $\begin{array}{l}\text { Explanatory/ } \\
\text { Indp }\end{array}$ & Neg \\
\hline
\end{tabular}

Table 3. Magnitude of Initial public offering listed at Bombay stock Exchange (Source: http/; www.bseindia.co.in)

\begin{tabular}{|c|c|c|c|c|c|c|c|c|c|c|c|}
\hline Year & BSE & BB & FPO & BB-Under & BB-Over & FPO-Under & FPO-over & $\%$ BBU & $\%$ BBO & $\% F P U$ & $\% F P O$ \\
\hline 2000 & 67 & 11 & 56 & 6 & 5 & 30 & 26 & 21.96 & -46.87 & 191.32 & -32.3 \\
\hline 2001 & 10 & 2 & 8 & 0 & 2 & 2 & 6 & 0.00 & -62.00 & 47.50 & -52.0 \\
\hline 2002 & 5 & 1 & 4 & 0 & 1 & 4 & 0 & 0.00 & -50.93 & 16.07 & 0.0 \\
\hline 2003 & 11 & 4 & 7 & 3 & 1 & 5 & 2 & 90.16 & -87.41 & 97.86 & -85.3 \\
\hline 2004 & 25 & 17 & 8 & 9 & 8 & 6 & 2 & 54.43 & -45.45 & 74.10 & -56.0 \\
\hline 2005 & 67 & 48 & 19 & 26 & 21 & 14 & 5 & 31.47 & -51.75 & 60.37 & -63.8 \\
\hline 2006 & 89 & 68 & 21 & 36 & 32 & 14 & 7 & 36.75 & -46.33 & 38.91 & -25.0 \\
\hline 2007 & 105 & 91 & 14 & 58 & 32 & 7 & 7 & 51.54 & -21.42 & 113.67 & -3.3 \\
\hline 2008 & 38 & 33 & 5 & 16 & 17 & 2 & 3 & 36.45 & -26.36 & 18.06 & -32.3 \\
\hline 2009 & 21 & 21 & 0 & 14 & 7 & 0 & 0 & 19.09 & -14.52 & 0.00 & 0.0 \\
\hline 2010 & 73 & 71 & 2 & 47 & 24 & 2 & 0 & 22.35 & -12.85 & 60.77 & 0.0 \\
\hline 2011 & 39 & 38 & 1 & 19 & 19 & 0 & 1 & 47.36 & -33.32 & 0.00 & -70.4 \\
\hline Total & 550 & 405 & 145 & 234 & 169 & 86 & 59 & 34.29 & -41.6 & 59.88 & -35 \\
\hline
\end{tabular}


Table 4. Unit root testing for stationary of dependent variable

\begin{tabular}{|c|c|c|c|c|c|c|c|}
\hline \multirow{2}{*}{\multicolumn{8}{|c|}{$\begin{array}{l}\text { Unit root test for stationary } \\
\text { Null Hypothesis: Unit root (individual unit root process) }\end{array}$}} \\
\hline & & & & & & & \\
\hline \multicolumn{8}{|c|}{ Exogenous variables: Individual effects } \\
\hline \multicolumn{8}{|c|}{ Automatic selection of maximum lags } \\
\hline \multicolumn{8}{|c|}{ Automatic lag length selection based on HQC: 0 to 1} \\
\hline \multicolumn{8}{|c|}{ Cross-sections included: 10} \\
\hline \multicolumn{5}{|l|}{ Method } & \multicolumn{2}{|c|}{ Statistic } & Prob.** \\
\hline \multicolumn{5}{|c|}{ Im, Pesaran and Shin W-stat } & \multicolumn{2}{|c|}{-24.8202} & 0.0000 \\
\hline \multicolumn{8}{|c|}{${ }^{\star *}$ Probabilities are computed assuming asymptotic normality } \\
\hline \multicolumn{8}{|c|}{ Intermediate ADF test results } \\
\hline Series & t-Stat & Prob. & $E(t)$ & $\mathrm{E}($ Var $)$ & Lag & Lag & Obs. \\
\hline DEPVAR & -10.475 & 0.0001 & -1.527 & 0.736 & 0 & 11 & 81 \\
\hline BB & -9.1161 & 0.0000 & -1.527 & 0.736 & 0 & 11 & 81 \\
\hline LOG_DIFF_IN_AG_ & -6.9439 & 0.0000 & -1.527 & 0.736 & 0 & 11 & 81 \\
\hline LGNOOFSHARE & -6.9077 & 0.0000 & -1.527 & 0.736 & 0 & 11 & 81 \\
\hline LOGMKTCAP & -6.8567 & 0.0000 & -1.527 & 0.736 & 0 & 11 & 81 \\
\hline LOGISSUESIZE & -6.8023 & 0.0000 & -1.527 & 0.736 & 0 & 11 & 81 \\
\hline LOGFORGP & -9.4394 & 0.0000 & -1.527 & 0.736 & 0 & 11 & 81 \\
\hline LOGFORNONP & -9.5012 & 0.0000 & -1.527 & 0.736 & 0 & 11 & 81 \\
\hline LOGINDNONP & -8.9226 & 0.0000 & -1.527 & 0.736 & 0 & 11 & 81 \\
\hline LOGSUBSC & -7.6882 & 0.0000 & -1.525 & 0.750 & 1 & 11 & 80 \\
\hline Average & -8.2653 & & -1.527 & 0.737 & & & \\
\hline
\end{tabular}

book build, and that is price through fixed price option. Data is collected with BSE websites and Capitaline database. However, we included all IPOs were listed at Bombay stock exchange (BSE), where we included both of two pricing mechanism techniques in our sample. Books build (BB), fixed price option (FPO), and Book build underpricing (BBU), Book build overpricing (BBO), fixed pricing underpricing (FPU) and fixed price overpricing (FPO).

Table 4 exhibits that the unit root testing to check the stationarity of data. We execute $\mathrm{Im}$, Person and Shin test to validate the unit root problem about the firm's age and other Ex-ante uncertainty. At the results, test statistics acquired the value of -24.82 , which reject the null hypothesis that contains that, Series is having a unit root problems. As the result, we reveal that there is no unit root problem exists in the model.

Table 5 reveals the descriptive results for all variables that are used in our probit regression model. We test probit regression model to identify the relationship between new issuing IPOs firms and the Ex- ante uncertainty determinants. Book building pricing mechanism (dummy variable), number of shares offered, difference in the days (difference between offer date and listing date), promoter's holdings including (Institutional promoters and retail promoters), market capitalization, and total subscription ratio and issue size of the IPOs. We analyze the various research tools such as, Mean, Median, Standard deviation, Skewness and kurtosis. Jarque-Bera test is used to determine the normality of the given series.

\section{Probit regression by (QML and Huber/White)}

Table 6 shows the Probit regression for Ex-ante uncertainty. The estimation equation and substituted coefficients are presented as follows.

Estimation equation: I_DEPVAR $=\mathrm{C}(1)+\mathrm{C}(2)^{\star} \mathrm{BB}+$ $\mathrm{C}(3)^{*}$ LOG_DIFF_IN_AG_ $+\mathrm{C}(4)^{*}$ LOGFORGP + $C(5)^{*}$ LOGFORNONP $+\mathrm{C}(6)^{*}$ LOGINDNONP + $\mathrm{C}(7)^{*}$ LOGISSUESIZE $+\mathrm{C}(8)^{*}$ LOGMKTCAP + C $(9)^{*}$ LOGSUBSC + C(10)*LGNOOFSHARE

Substituted coefficients: DEPVAR = 1-@CNORM($2.83137641426-0.83434904126^{*} \mathrm{BB}-0.398312271571^{\star}$ LOG_DIFFIN_AG + 0.222661553064* LOGFORGP + $0.486435625654^{*}$ LOGFORNONP - $0.0626172297357^{*}$ LOGINDNONP - $1.6183493561{ }^{*}$ LOGISSUESIZE + $0.892966445683^{*}$ LOGMKTCAP - $0.338673777398^{*}$ LOGSUBSC + 0.333195239581*LGNOOFSHARE)) 
Table 5. Descriptive results including Ex-ante uncertainty

\begin{tabular}{|c|c|c|c|c|c|c|c|c|c|c|}
\hline Name & DEPVAR & BB & NOOFSHARE & DIFFINAG & FORGP & FORNONP & INDNONP & MKTCAP & SUBSC & ISSUESIZE \\
\hline Mean & 0.10 & 0.97 & 16.55 & 2.97 & 0.32 & 1.78 & 2.57 & 7.09 & 1.95 & 5.41 \\
\hline Median & 0.00 & 1.00 & 15.96 & 2.94 & 0.00 & 2.13 & 2.85 & 6.72 & 1.79 & 4.98 \\
\hline Maximum & 1.00 & 1.00 & 21.24 & 3.80 & 4.31 & 3.74 & 4.20 & 12.28 & 4.53 & 9.64 \\
\hline Minimum & 0.00 & 0.00 & 14.64 & 2.63 & 0.00 & -2.99 & -4.44 & 4.17 & 0.00 & 3.14 \\
\hline Std. Dev. & 0.31 & 0.15 & 1.50 & 0.21 & 1.03 & 1.28 & 1.33 & 1.93 & 1.27 & 1.61 \\
\hline Skewness & 2.49 & -6.16 & 1.25 & 1.11 & 2.96 & -0.88 & -2.19 & 0.81 & 0.17 & 0.84 \\
\hline Kurtosis & 7.23 & 39.02 & 3.76 & 4.93 & 10.2 & 3.65 & 10.92 & 2.87 & 1.73 & 2.81 \\
\hline Jarque-Bera & 146.46 & 4953.82 & 23.54 & 29.89 & 297.60 & 12.14 & 280.52 & 9.16 & 5.93 & 9.97 \\
\hline Probability & 0.00 & 0.00 & 0.00 & 0.00 & 0.00 & 0.00 & 0.00 & 0.01 & 0.05 & 0.00 \\
\hline Sum & 9.00 & 80.00 & 1357.13 & 243.54 & 26.93 & 146.15 & 210.91 & 581.86 & 160.60 & 444.14 \\
\hline Sum Sq. Dev. & 8.01 & 1.95 & 184.02 & 3.77 & 86.55 & 133.58 & 144.32 & 303.49 & 132.56 & 212.44 \\
\hline Observations & 82 & 82 & 82 & 82 & 82 & 82 & 82 & 82 & 82 & 82 \\
\hline
\end{tabular}

\section{DISCUSSION}

Derived on the binary Probit regression results, it was considered that the entire variables were regressed against the level of underpricing. There is no significant association between book build pricing mechanism, and the new firms age at $5 \%$ significance level $(z=-1.11)$. Therefore, the null hypothesis is accepted. A result reveals that there is no weighty relationship between offer timing, and the new firms age at $5 \%$ significance level ( $z$ $=-.37)$. As the results, the null hypothesis is acknowledged. It reveals that there is no significant link between foreign promoters and degree of underpricing at $5 \%$ significance level $(z$ $=1.147$ ). In addition to, the null hypothesis is accepted. It examines for no consequential association between institutional non promoters and level of underpricing at $5 \%$ significance level $(z=-.381)$. There is no significant link between institutional non promoters and underpricing. For this reason, a null hypothesis is accepted.

There is a relevant association between non institutional non promoters with a degree of underpricing at $5 \%$ significant level $(z=2.7075)$. It indicates that, there is a positive significant relationship between non institutional non promoters and firm's age. Nevertheless, the nul hypothesis is rejected. It founded for significant relation of issue size at the level of underpricing at $5 \%$ significance level $(z=-2.05)$. It expresses the negative link between numbers of share offered with the firm's age. Therefore, the null hypothesis is rejected. There is a weighty association between market capitalization with firm's age at $5 \%$ significant level $(z=1.6775)$. It indicates that, there is a positive significant relationship between market capitalization and firm's age. At the same time, the null hypothesis is rejected. Results disclose the significant association between subscription with the firm's age at $5 \%$ significance level $(z=-1.96)$. It obtains the negative association between subscription rate and the firm's age. At consequences, the null hypothesis is rejected. It founded for no significant relation of the number of share offered at the level of underpricing at $5 \%$ significance level $(z=-1.005)$. It expresses no link between numbers of share offered with the firm's age. Therefore, the null hypothesis is accepted.

\section{Conclusions}

Taking into account all firms which contain finished public on the official market of the Stock Exchange of Bombay for the period 2008 until 2011, this study examines the evidence on the short-run under-pricing of IPOs.

In particular, an average underpricing level within 
Table 6. Probit regression for Ex- ante uncertainty

\begin{tabular}{|c|c|c|c|c|}
\hline \multicolumn{5}{|c|}{ Dependent variable: DEPVAR } \\
\hline \multicolumn{5}{|c|}{ Method: ML - Binary Probit (Quadratic hill climbing) } \\
\hline \multicolumn{5}{|c|}{ Included observations: 82} \\
\hline \multicolumn{5}{|c|}{ Convergence achieved after 6 iterations } \\
\hline \multicolumn{5}{|c|}{ QML (Huber/White) standard errors and covariance } \\
\hline Variable & Coefficient & Std. Error & z-Statistic & Prob. \\
\hline C & -2.8313 & 6.7598 & -0.418 & 0.6753 \\
\hline BB & -0.83434 & 0.746 & -1.110 & 0.2634 \\
\hline LOG_DIFF_I & -0.39831 & 1.065 & -0.373 & 0.7087 \\
\hline LOGFORGP & 0.22266 & 0.1949 & 1.142 & 0.2533 \\
\hline LOGNONISNONP & 0.48643 & 0.2345 & 2.073 & $0.031^{*}$ \\
\hline LOGINSTNONP & -0.06261 & 0.164374 & -0.380 & 0.7032 \\
\hline LOGISSUESI & -1.61834 & 0.7857 & -2.059 & $0.034^{*}$ \\
\hline LOGMKTCA & 0.89296 & 0.5332 & 1.674 & $0.09^{* *}$ \\
\hline LOGSUBSC & -0.33867 & 0.1725 & -1.963 & $0.046^{*}$ \\
\hline LGNOFSHRE & 0.33319 & 0.3304 & 1.008 & 0.3134 \\
\hline McFadden R-squared & 0.262492 & \multicolumn{2}{|c|}{ Mean dependent var. } & 0.109756 \\
\hline S.D. dependent var & 0.314509 & \multicolumn{2}{|c|}{ S.E. of regression } & 0.277957 \\
\hline Akaike info criterion & 0.754266 & \multicolumn{2}{|c|}{ Sum squared resid. } & 5.562709 \\
\hline Schwarz criterion & 1.047768 & \multicolumn{2}{|c|}{ Log likelihood } & -20.92489 \\
\hline Hannan-Quinn criter. & 0.872102 & \multicolumn{2}{|l|}{ Deviance } & 41.84979 \\
\hline Restr. deviance & 56.74484 & \multicolumn{2}{|c|}{ Restr. log likelihood } & -28.37242 \\
\hline LR statistic & 14.89505 & \multicolumn{2}{|c|}{ Avg. log likelihood } & -0.255182 \\
\hline Prob. (LR statistic) & 0.093859 & & & \\
\hline Obs with $\mathrm{Dep}=0$ & 73 & \multicolumn{2}{|l|}{ Total obs. } & 82 \\
\hline Obs with $\mathrm{Dep}=1$ & 9 & & & \\
\hline
\end{tabular}

the range $50 \%$ is found based on first day. Using a probit regression approach, the degree of underpricing in terms of new firm's age is explained by the ex-ante uncertainty hypothesis and the ownership structure hypothesis. However, there is limited support for the signaling hypothesis. In particular, the results show that the exante information and have a significant positive impact on the initial returns while the ownership structure has a significant negative effect on short-run underpricing. The results obtained from this study show that new issues on the BSE are subject to underpricing, consistent with developed and other emerging markets. In this respect, prospective investors should pursue the strategy of buying the new issues at the offer and selling them immediately on the first day of trading. However, the study also reveals that investors should not hold new issues very long as the highest component of the initial returns is establish on the first day of trading.

\section{Future implication}

The pricing and valuation of new issue companies has received a lot of interest in the academic community. Many theoretical models have been developed to explain how entrepreneurs can convey their private knowledge about the IPO to potential investors. Models explaining the widespread occurrence of underpricing have also been derived. There have been a number of empirical tests of some of the signaling models and the evidence in support of theory has been mixed. These tests have been primarily based on Indian IPOs data and the results do not necessarily extend to Indian and other Asian markets. This paper, therefore, set out to examine whether new issues in India provide support for various extant signaling models. In India, the regulator SEBI is not involved in the choice of the grading agency it is completely at the discretion of the issuer. So there can be 
potential conflict of interest especially if the rating agency that assigns IPO grading has already involved in assigning credit rating for any other instrument (for example bonds) issued by the same issuer. To find out if our study suffers from such problems, we checked all the prospectus of the graded IPOs in our sample and found that none of those IPOs have outstanding bond issues in the pre-IPO period. It can also be argued that the conflict of interest may still hold if IPO firms can negotiate a better grading by committing to provide future business to the same rating agency. To address this issue for the graded IPOs that has raised the debt securities, from the IPO issue date to $31 \mathrm{Dec}, 2011$. Notwithstanding, we acquired their credit rating agency's name and the rating given by those agencies from PROWESS database of CMIE.

\section{REFERENCES}

Allen F, Faulhaber G (1989). Signaling by under pricing in the IPO market. Journal of Financial Economics. 23: 303-323.

Baker M, Wurgler J (2007). Investor Sentiment in the Stock Market. Journal of Economic Perspectives. 21: 129-151.

Bansal R, Khanna A (2012). Post Indian stock market's crisis and its impact on IPOs underpricing: Evidence from 2008-2011. Asian journal of management research. 3(1): 01-11.

Bansal R, Khanna R (2012a). Share holding's pattern and its impact on IPO Underpricing: after Indian stock market crisis in 2008. Asian journal of research in business, economics and management. 2(8): 159-174.

Benveniste LM, Spindt PA (1989). How investment bankers determine the offer price and allocation of new issues. Journal of Financial Economics. 24: 343-361.
Ibbotson RG (1975). Price performance of common stock new issues. Journal of Financial Economics. 2: 235-272.

Ibbotson RG, Ritter JR (1995). Initial public offerings, Chapter 30. In: Jarrow R, Maksimovic V, Ziemba W (Eds.), Handbooks in Operations Research and Management Science: Finance. Elsevier B.V, Amsterdam: $993-1016$.

Loughran T, Ritter JR (1994). Initial Public Offerings: international insights. Pacific Basin Finance Journal. 2: 165-199.

Kumar SSS (2010). Is book building an efficient pricing mechanism? The Indian evidence. International research journal of finance and economics. 38: 173-189.

Megginson WL, Weiss KA (1991). Venture capitalist certification in initial public offerings. Journal of Finance. 46: 879-903.

Muscarella C J, Vetsuypens M R (1989). A simple test of Baron's model of IPO underpricing. Journal of Financial Economics. 24: 125-135.

McDonald JG, Fisher AK (1972). New Issues Stock Price Behavior. Journal of Finance. 12: 97-102.

McGuinness P (1992). An examination of the under-pricing of initial public offerings in Hong Kong: 1980 - 90. Journal of Business Finance and Accounting, 19: 165-186.

Rock K (1986). Why new issues are underpriced? Journal of Financial Economics. 15: 187-212.

Welch I (1989). Seasoned offerings, imitation costs and the under pricing of initial public offerings. Journal of Finance. 47: 695-732. 